\title{
REKONSTRUKSI SISTEM MELALUI PENDEKATAN PENDIDIKAN UNTUK PEMBANGUNAN YANG BERKELANJUTAN
}

\author{
SUSILAWATI \\ Pembina Yayasan Nabil Al-Fatih Bintan, Kepulauan Riau, susiari_76@yahoo.co.id \\ MUHAMMAD ADLAN NAWAWI \\ Institut PTIQ Jakarta, adlan_nawawi@yahoo.com
}

ABD MUID N

UIN Syarif Hidayatullah Jakarta, mailto:balesaloe@gmail.com

\begin{abstract}
Abstrak
Implementasi sistem pendidikan nasional dipandang belum mampu menjawab berbagai persoalan yang melibatkan peserta didik. Di balik usaha sistemik yang dirumuskan dalam serangkaian regulasi dan kebijakan, seragkaian fenomena kekerasan, degradasi moral dan kerusakan tatanan sosial-kemasyarakatan masih menempatkan dunia pendidikan sebagai salah satu aktor. Tidak hanya peserta didik, tapi juga kalangan pendidik. Kegelisahan semakin mengemuka saat tujuan ideal pendidikan nasional tidak sepenuhnya mampu menghasilkan sistem pendidikan yang menata bangunan karakerter kebangsaan dan keagamaan, serta menghasilkan kecerdasan yang tidak sekedar bersifat artifisial, tapi mampu menginsiprasi kehidupan sosial-kemasyarakat yang berintegritas. Tulisan ini hendak menunjukkan bahwa sistem konvensional tidak lagi cukup relevan untuk diterapkan dalam paradigma pendidikan modern. Pendidikan harus berorientasi masa depan yang menggabungkan segala kebutuhan dan kepentingan tantangan masa depan. Atas dasar itu, pendidikan untuk pembangunan berkelanjutan haruslah dipertimbangkan sebagai sebuah paradigma yang diimplementasikan dalam rumusan jangka panjang.
\end{abstract}

Kata Kunci: Perubahan Sosial, Paradigma, Pendidikan Modern, Pendidikan Berkelanjutan

\begin{abstract}
Implementation of the national education system is seen as not being able to answer various problems involving students. Behind the systemic efforts formulated in a series of regulations and policies, a series of phenomena of violence, moral degradation and damage to the social-social order still make the world of education as one of the actors. Not only students, but also among educators. That's Anxiety arises when the ideal goal of national education is not fully able to produce an education system that arranges national and religious character building, and produces intelligence that is not merely artificial, but is able to inspire social life with integrity. This paper wants to show that the conventional system is no longer relevant enough to be applied in the modern education paradigm. Education must be future oriented which combines all the needs and interests of future challenges. On that basis, education for sustainable development must be considered as a paradigm that is implemented in a long-term formula
\end{abstract}

Keywords: Social change, Paradigm, Modern Education, Continuing Education 


\section{A. PENDAHULUAN}

Runtuhnya kekuasaan Orde Baru melahirkan perubahan dalam berbagai dimensi kehidupan bangsa. Perubahan tersebut tidak hanya berlangsung pada tataran konsep bangunan kebangsaan dan keindonesiaan, tapi juga perubahan paradigma berbangsa dan bernegara. Perubahan itulah yang terjadi dalam tatanan kehidupan sosial, politik, ekonomi maupun budaya. Perubahan itu juga terjadi dalam bidang pendidikan, yang pada dasarnya merupakan reposisi dan rekonstruksi pendidikan secara keseluruhan. Reposisi dan rekonstruksi yang melibatkan penilaian kembali secara kritis berbagai pencapaian dan masalahmasalah yang dihadapi dunia pendidikan nasional. ${ }^{1}$

Rekonstruksi paradigma pendidikan nasional memiliki landasan argumentasi yang cukup jelas, mengingat pencapaian dan masalah yang dihadapai oleh dunia pendidikan tidak saling memberi jawaban bagi eksistensi masing-masing. Rekonstruksi paradigma tersebut menemukan momentum yang tepat tatkala perubahan multidimensi juga diamanatkan oleh undang-undang, sehingga memiliki legalitas formal. Pasal 1 ayat (2) UU Sistem Pendidikan Nasional No. 20 tahun 2003 menyebutkan "pendidikan nasional adalah pendidikan yang berdasarkan pancasila dan Undang-Undanga Dasar Negara Republik Indonesia tahun 1945 yang berkar pada nilai-nilai agama, kebudayaan nasional Indonesia dan tanggap terhadap perubahan zaman. Meski demikiran, di balik pencapaian yang belum sepenuhnya terwujud, serangkaian masalah justru menghadang dan mengiringi pencapaian-pencapaian itu sendiri.

Hal itulah yang tergambar dalam perjalanan dunia pendidikan Indonesia dewasa ini. Di tengah perubahan konsep dan paradigma yang begitu signifikan, sejumlah perosoalan yang mendera pun tidak kunjung berakhir. Di tengah upaya pemerintah meningkatkan besaran anggaran bagi dunia pendidikan dengan segala bentuk program bantuan yang memudahkan warga negara dalam menempuh pendidikan, angka kekerasan justru semakin mengalamai peningkatan. Tidak hanya melibatkan siswa (anak didik), namun juga guru (pendidik) dan orang tua siswa.

Pada tahun 2012, Komisi Perlindungan Anak Indonesia (KPAI) menyatakan tindak kekerasan terhadap anak di lingkungan pendidikan mengalami konstalasi yang kompleks dan memprihatinkan, hingga peningkatan. Berdasarkan survey dari 9 provinsi dengan responden lebih dari 1000 siswa sekolah dasar, menengah dan atas, sebanyak $87,6 \%$ mengaku mengalami tindak kekerasan, baik dari sesama siswa, guru, maupun orang tua. ${ }^{2}$ Sementara itu, pada tahun 2013. KPAI juga melaporkan bahwa terdapat 255 kasus tawuran antar

\footnotetext{
${ }^{1}$ Azyumardi Azra, Paradigma Baru Pendidikan Nasional (Jakarta: Penerbit Kompas, 2002), xiii

2 http://www.radioaustralia.net.au/indonesian/2012-12-20/kekerasan-di-sekolah-meningkatmendesak-kebijakan-sekolah-ramah-anak/1063558. Dikutip pada 10 Juni 2014
} 
pelajar selama tahun 2013. Jumlah ini meningkat dari 147 kasus selama tahun 2012. ${ }^{3}$ Selain contoh kekerasan tersebut di atas, dunia pendidikan pun masih menerima kenyataan bahwa penyerapan tenaga kerja dari tahun ke tahun didominasi oleh penduduk yang berpendidikan rendah, yaitu sekolah dasar ke bawah. Jumlah itu bahkan mencapai 52 juta orang atau $46.95 \%$ pada tahun $2013 .{ }^{4}$ Sementara tenaga kerja yang Indonesia yang berpendidikan diploma maupun perguruan tinggi tidak mencapai $10 \%$.

Kajian utama dalam pembahasan penelitian ini adalah paradigma baru pendidikan modern. Paradigma baru ini merujuk pada implementasi konsep ESD dalam sistem pendidikan nasional dan sistem pendidikan Islam yang didekati dengan perspektif qur'anik. Untuk itu, memakai beberapa teori yang terkait dengan perubahan sosial (social change), visi pendidikan nasional dan Islam serta pendekatan qur'anik yang memakai perspektif tafsir tematik.

Perubahan sosial merupakan bagian penting dalam kajian sosiologi. Perubahan-perubahan tersebut meliputi unsu-unsur kebudayaan, baik yang bersifat material maupun imaterial. ${ }^{5}$ Secara perubahan sosial dimaksudkan sebagai perubahan-perubahan yang terjadi dalam struktur dan fungsi massyarakat. Gillin dan Gillin mengatakan bahwa perubahan sosial sebagai suatu variasi dari cara-cara hidup yang telah diterima, baik karena perubahan geografis, kebudayaan material, komposisi penduduk, ideologi ataupun penemuanpenemuan baru. Berbagai penyebab perubahan tersebut bisa disebabkan faktor internal, maupun eksternal. ${ }^{6}$ Sementara itu, Selo Soemardjan menyatakan bahwa rumusan perubahan sosial adalah segala perubahan pada lembaga-lembaga kemasyarakatan d dalam masyarakat yang mempengaruhi sistem sosialnya, termasuk nilai, sikap dan perilaku di antara kelompok masyarakat. ${ }^{7}$

Sementara itu, visi pendidikan nasional dan pendidikan Islam bisa dipandang dari segi pemaknaan tentang visi yang berarti penglihatan, daya lihat, pandangan, impian atau bayangan. ${ }^{8}$ Dengan demikian, visi mengacu pada citacita, keinginan, khayalan atau impian ideal yang ingin dicapai, yang dirumuskan secar singkat dan padat namun memiliki makna luas dan jauh ke depan.

Pendekatan qur'anik dimaksud sebagai pendekatan yang didasarkan pada Al-Qur'an dan Hadis yang secara umum menjadi ajaran Islam. Pendekatan qur'anik yang bersifat universal didekati dengan perpsketif tafsir tematik

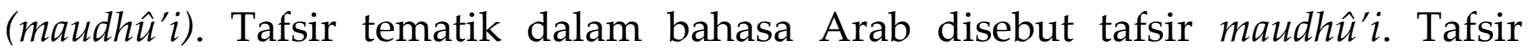

3 http://sinarharapan.co/index.php/news/read/29900/2013-tawuran-pelajar-meningkat-tajam. html. Dikutip pada 10 Juni 2014.

${ }^{4}$ Badan Pusat Statistik, No. 78/11/Th.XVI, 6 November 2013.

${ }^{5}$ Soerjono Soekanto, Sosiologi, hal. 336.

${ }^{6}$ Soerjono Soekanto, Sosiologi, hal. 336-337

7 Soerjono Soekanto, Sosiologi, hal. 337.

8 John M. Echols dan Hasan Shadily, Kamus Inggris-Indonesia (Jakarta: Gramedia, 2003), 631. 
maudh $\hat{u}^{\prime} i$ terdiri dari dua kata, yaitu kata tafsir dan kata maudhô'i. Kata tafsir termasuk bentuk masdar (kata benda) yang berarti penjelasan, keterangan,

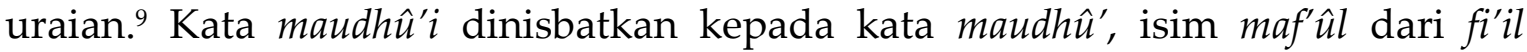
madhi wadha'a yang memiliki makna beraneka ragam, yaitu yang diletakkan, yang diantar, yang ditaruh, ${ }^{10}$ atau yang dibuat-buat, yang dibicarakan, tema, atau topik. ${ }^{11}$ Makna yang terakhir ini (tema atau topik) yang relevan dengan konteks pembahasan di sini. Secara harfiah tafsir maudh $\hat{u}^{\prime} i$ dapat diterjemahkan dengan tafsir tematik, yaitu tafsir berdasarkan tema atau topik tertentu.

Pengertian tafsir tematik (maudh $\left.\hat{u}^{\prime} i\right)$ secara terminologi banyak dikemukakan oleh para pakar tafsir yang pada prinsipnya bermuara pada makna yang sama. Salah satu definisi maudhû'i/tematik yang dapat dipaparkan di sini ialah definisi yang dikemukakan Abdul Hayyi al-Farmawi sebagai berikut, yaitu pola penafsiran dengan cara menghimpun ayat-ayat al-Quran yang mempunyai tujuan yang sama dalam arti sama-sama membicarakan satu topik dan menyusun berdasarkan masa turun ayat serta memperhatikan latar belakang sebab-sebab turunnya, kemudian diberi penjelasan, uraian, komentar dan pokok-pokok kandungan hukumnya. ${ }^{12}$

Definisi tafsir maudh $\hat{u}^{\prime} i$ (tematik) ini memberikan indikasi bahwa penafsir yang menggunakan metode dan pendekatan tematik dituntut harus mampu memahami ayat-ayat yang berkaitan dengan topik yang dibahas, maupun menghadirkan dalam pikiran pengertian kosa kata ayat dan sinonimnya yang berhubungan dengan tema yang ditetapkan. Penafsir menyusun runtutan ayat sesuai dengan masa turunnya dalam upaya mengetahui perkembangan petunjuk al-Quran menyangkut persoalan yang dibahas, menguraikan satu kisah atau kejadian membutuhkan runtutan kronologis peristiwa. Mengetahui dan memahami latar belakang turun ayat (bila ada) tidak dapat diabaikan, karena hal ini sangat besar pengaruhnya dalam memahami ayat-ayat al-Quran secara benar. Untuk mendapatkan keterangan yang lebih luas, penjelasan ayat, dapat ditunjang dari hadis, perkataan para sahabat, dan lain-lain yang ada relevansinya.

\section{B. METODE}

${ }^{9}$ Louis Ma'lûf, Qâmûs al-Munjî̀ Fî al-Lughah wa al-A'lâm (Beirut: Mathba'ah al-Katulikiyyah, 1927), 613.

10 Muhammad Idris Al-Marbawi, Qâmûs al-Marbawî (Mesir: Mushthafâ al-Bâbî al-Halabî, 1350), 391.

${ }^{11}$ Muhammad Idris Al-Marbawi, Qâmûs al-Marbawî, 1004.

12 Abd al-Hayyi Al-Farmawi, Al-Bidâyah Fî al-Tafsîr al-Maudhû́'I (Kairo: al-Hadhârât alGharbiyyah, 1977), 52. 
Penelitian ini merupakan jenis penelitian deskriptif analitik (descriptive research) ${ }^{13}$, yaitu suatu penelitian yang mendeskripsikan data, fakta, dan kecenderungan yang terjadi, yang kemudian dianalisis dan direkomendasikan mengenai apa yang harus dibangun untuk mencapai suatu keadaan. Namun, di lihat dari segi objeknya, penelitian ini termasuk jenis penelitian kepustakaan (library research). ${ }^{14}$ Di tinjau dari tujuannya, penelitian ini termasuk penelitian eksploratif 15 sebagai upaya untuk menemukan secara faktual, akurat dan sistematis terhadap fakta dan data tentang konsep pengembangan profesional guru secara berkelanjutan (CPD).

Berdasarkan jenis penelitiannya, maka pendekatan yang sesuai adalah pendekatan fungsional. Pendekatan fungsional bekerja dengan penekanan pada segi kemanfaatannya bagi masyarakat akademik dan para pelaku pendidikan. Pendekatan fungsionalisme melihat interelasi antara fungsi masyarakat dengan budaya. Dalam konteks penelitian ini, pendekatan fungsionalisme melihat apakah perubahan sosial mendorong lahirnya sebuah paradigma baru. ${ }^{16}$ Pendekatan ini menuntut dilakukan upaya dan langkah untuk mencapai tujuan tersebut.

\section{Hasil Pembahasan}

\section{Konstruksi Sistem Pendidikan}

Contoh-contoh yang disebut dalam pendahuluan di atas hanyalah beberapa yang muncul dari beberapa kasus yang berkembang dewasa ini. Tentu saja, masih banyak contoh lain yang bisa diungkap dengan sekumpulan data dan fakta di lapangan. Meski tidak semua pihak menyatakan bahwa contoh-contoh tersebut merupakan hasil karya dari dunia pendidikan selama ini, namun contohcontoh tersebut tidak menafikan kenyataan bahwa pendidikan nasional dengan

${ }^{13}$ Descriptive research yakni memusatkan pada gambaran yang akurat dari karakteristik suatu keadaan atau fenomena yang terjadi. Penelitian ini berusaha untuk membuat deskripsi fenomena yang diselidiki dengan cara melukiskan dan mengklasifikasikan fakta dan karakteristik fenomena tersebut secara faktual dan cermat. Jadi penelitian ini digunakan untuk menjawab pertanyaan tentang apa dan bagaimana keadaan sesuatu (fenomena atau kejadian) dan menjelaskan keadaan yang sebenarnya. Dengan demikian, setelah suatu fenomena dideskripsikan, maka jenis penelitian lainnya (korelasional, diferensial, dan kausal) dapat dilakukan. Lihat Burke Johson \& Larry Christensen, Educational Research Quantitative, Qualitative, and Mixed Approaches, (Boston: Pearson Education, 2004), 437.

14 Sumardi Suryabrata, Metodologi Penelitian, Jakarta: RajaGrafindo Persada, 2006,Ed.I, h.18. Bahan dan sumber tertulis yang digunakan adalam penelitian yaitu buku, ensiklopedia, jurnal, tesis dan dokumen lainnya yang sesuai dengan prinsip kemutakhiran (recency) dan prinsip relevansi (relevance). Lihat juga Abuddin Nata, Metodologi Studi Islam (Jakarta: RajaGrafindo Persada, 2003), 125.

${ }^{15}$ Muhammad Nazir, Metode Penelitian (Jakarta:Ghalia Indonesia, 1998), 66-74.

16 Dalam tatapan fungsionalisme, seorang functionalist viewed culture as a collection of integraetd parts that work together to keep a society functioning. Lihat Microsoft Encarta Encyclopedia CD-ROM, 2001, entry "Functionalism". 
beragam perubahan paradigma belum mampu sepenuhnya melahirkan manusiamanusia yang berbudaya.

Bahkan, menurut Tilaar, eksistensi pendidikan yang berkembang saat ini cenderung mengekslusi anak didik dalam dunia yang tertutup. Pendidikan telah mengisolasi manusia dari sesamanya, dari masyarakatnya, dan dari tanggung jawabnya sebagai sesama manusia. Sebaliknya pula, manusia-manusia produk pendidikan lahir sebagai manusia-manusia yang tidak bertanggung jawab dan tidak berbudaya (not civilized). ${ }^{17}$ Pandangan tentang kegagalan insitusi pendidikan dalam melahirkan manusia-manusia yang bertanggung jawab dan berbudaya inilah yang sebelum menjadi fokus perhatian para pemikir kritis tentang dunia insitusi pendidikan. Ivan Illich bahkan menganggap bahwa pendidikan di dunia modern telah gagal mewujudkan tujuan ideal pendidikan itu sendiri. Pendidikan modern telah gagal, dan hanya menghasilkan de-humanisasi belaka. Sebab itu, Illich menyimpulkan bahwa lembaga pendidikan modern tidak akan membawa perubahan apa-apa. Struktur pendidikan hanya akan memperkuat struktur elit yang telah mapan. Karena itu, semua sistem persekolahan harus dihapuskan. ${ }^{18}$

Pandangan kritis tentang sistem pendidikan bersumber dari tinjauan atas hasil-hasil proses pendidikan yang tidak sepenuhnya sejalan dengan tujuan pendidikan itu sendiri. Kesukesan dan kegagalan sistem pendidikan pun akan disimpulkan dari produk-produk pendidikan yang sejalan atau tidak sejalan dengan amanat tujuan pendidikan yang dimaksud. Karena itu, menurut Winarno Surakhmad, ukuran keberhasilan pendidikan di Indonesia ialah sejauhmana pendidikan nasional merupakan usaha yang relevan ditinjau dari amanah konstitusi, yakni mencerdaskan kehidupan bangsa. ${ }^{19}$ Lebih lanjut Winarno mengatakan bahwa ukuran itu juga bisa dilihat dari sejauhmana pendidikan mendatangkan kesejahteraan bagi bangsa, membangun bangsa yang bermartabat, kokoh dan maju. ${ }^{20}$

Amanat konstitusional yang termaktub dalam Pembukaan UUD 1945 cukup memberi garis tegas tentang tujuan, arah dan cita-cita kehidupan bangsa dan negara, yakni melindungi segenap bangsa Indonesia dan seluruh tumpah darah Indonesia, memajukan kesejahteraan umum dan mencerdaskan kehidupan bangsa, ikut melaksanakan ketertiban dunia. Salah satu poin penting dalam tujuan, arah dan cita-cita tersebut terkait dengan peran pendidikan untuk mencerdaskan kehidupan bangsa. Hal itulah yang diimplementasikan dalam UU RI No 2 tahun 2003 tentang Sistem Pendidikan

17 H.A.R. Tilaar, Perubahan Sosial dan Pendidikan (Jakarta: Grasindo, 2002), xxxvi.

18 Azyumardi Azra, Paradigma Baru Pendidikan Nasional, 149. Lihat juga, Ivanm Illich, Deschooling Society, 1970, 13-15, yang dipublikasikan oleh http://philosophy.la.psu.edu/

19 Winarno Surakhmad, Pendidikan Nasional: Strategi dan Tragedi (Jakarta: Penerbit Kompas, 2009), 91.

${ }^{20}$ Winarno Surakhmad, Pendidikan Nasional: Strategi dan Tragedi, 91. 
Nasional Pasal 3, yang menyebutkan tujuan pendidikan nasional berfungsi mengembangkan kemampuan dan membentuk watak serta peradaban bangsa yang bermartabat dalam rangka mencerdaskan kehidupan bangsa, bertujuan untuk berkembangnya potensi peserta didik agar menjadi manusia yang beriman dan bertakwa kepada Tuhan Yang Maha Esa, berakhlak mulia, sehat, berilmu, cakap, kreatif, mandiri, dan menjadi warga negara yang demokratis serta bertanggung jawab.

Berdasarkan rumusan konstitusi tersebut, eksistensi pendidikan, baik secara konseptual maupun praktikal merupakan sebentuk transformasi sosial yang mewujudkan manusia-manusia sebagaimana yang tersebut dalam undang-undang tersebut. Dengan demikian, sistem pendidikan nasional sejatinya merupakan rumusan komprehensif yang berorientasi pada wujud manusia transformatif.

Menurut Tilaar, aspek tranformasi itulah yang mengindikasikan bahwa proses pendidikan menggambarkan penyatuan wawasan individu dengan dunia luas. Dunia yang tidak hanya merupakan sekumpulan individu lain, tapi juga makhluk di luar dirinya, horizon di luar horizon dirinya, serta sistem yang hidup mengitari individu (lebenswelt). ${ }^{21}$ Dalam konteks ini terjalin hubungan antara inividu dengan dunianya. Jalinan tersebut tidak terbungkus dalam ekslusifisme atau egoisme, melainkan jalinan partisipatif.

Individu partisipatif hanya dapat terjadi apabila individu tersebut mempunyai kemampuan-kemampuan yang telah dikembangkan melalui proses individuasi. Selanjutnya, individu tersebut memiliki kemampuan untuk mentransformasikan dunianya dengan ikut berpartisipasi di dalam proses transformasi tersebut dengan kreatifitas yang ia miliki. ${ }^{22} J a l i n a n$ inividu dengan dunia dirinya secara partisipatif merupakan rangkaian sistem pendidikan yang bersifat kontruktivis. ${ }^{23}$ Dengan demikian, pola jalinan seperti di atas bisa dilihat dalam relasi individu dengan perspektif sosial, berupa sebuah konsepsi yang menawarkan basis pengetahuan yang bersifat kontruktivistik. Pengetahuan dikonstruksi melalui hubungan internal dan eksternal yang merepresentasikan materi pengetahuan (content knowledge) yang diperoleh individu dalam memerankan dirinya. ${ }^{24}$

Relasi individu dengan dunia di luar dirinya merupakan tindakan pembelajaran dan pendidikan yang memandang segala proses tersebut sebagai peristiwa sosial, gejala ruhani dan tindakan manusiawi dalam hubungannya dengan alam, manusia dan sistem nilai. Unsur material pendidikan pada umumnya terhimpun dalam suatu tindakan belajar, mengajar dan mendidik yang secara mikro dikenal sebagai tindakan pembelajaran dan pendidikan, dan secara

${ }^{21}$ H.A.R. Tilaar, Perubahan Sosial dan Pendidikan, hal. xli.

${ }^{22}$ H.A.R. Tilaar, Perubahan Sosial dan Pendidikan, hal. xli.

${ }^{23}$ Konstruktivisme merupakan salah satu filsafat pengetahuan yang menekankan bahwa pengetahuan kita adalah konstruksi kita sendiri. Pengetahuan bukan sebagai hasil pemberian orang lain tetapi merupakan hasil dari konstruksi yang dilakukan oleh setiap individu. Paul Suparno, Filsafat Konstruktivisme dalam Pendidikan (Yogyakarta: Kanisius, 1997), 24. Lihat juga Wina Sanjaya, Pembelajaran dalam Implementasi Kurikulum Berbasis Kompetensi (Bandung: Sinar Baru Algesindo, 2001), 111.

${ }^{24}$ Jukka Husu, “Analyzing Teacher Knowledge in its" Interactional Positioning, 118. 
makro terprogram dalam kegiatan belajar dan mengajar. Landasannya tidak lepas dari pandangan tentang hakikat manusia, yang dikenal dengan beberapa istilah, yakni animal educandum, animal symbolicum, homo religius dan zoon politicon. ${ }^{25}$

Analisa keilmuan tentang kegiatan pendidikan di sekolah secara makro menunjukkan bahwa penciptaan program-program pembelajaran dan pendidikan memerlukan berbagai landasan ilmu pengetahuan secara interdisipliner. Terkait dengan itu, analisis interdisipliner dan multidisipliner tidak bisa dipisahkan. Analisa tersebut menyangkut kegiatan ilmiah yang merupakan gejala ruhani, peristiwa sosial, dan hubungan nilai. ${ }^{26}$

Gejala ruhani berarti perkembangan ruhani antara anak menjadi dewasa dalam konteks hubungan ruhani antara guru dengan pengetahuan yang diperolehnya. Peristiwa sosial merupakan tindakan sosialisasi dari generasi tua ke genarasi muda yang juga merupakan hubungan antarindividu dan hubungannya dengan kelompok sosial dalam konteks lokal, nasional dan internasional. Sementara itu, hubungan nilai dan norma berarti dalam kegiatan pembelajaran dan pendidikan terjadi transaksi nilai atau simbol yang asimetris.

Gejala-gejala yang ada adalah produk kehidupan sosial-kemasyarakatan. Pendidikan dalam arti yang lebih kompleks, baik dilakukan oleh guru maupun siswa adalah proses transmisi pengetahuan (transfer of knowledge), sikap, kepercayaan dan keterampilan yang pada dasarnya inheren dengan kehidupan masyarakat. Segala aktivitas pengetahuan merupakan hasil hubungan individu dengan orang lain di sekitarnya, di berbagai lingkungan kehidupan yang selalu mengandaikan adanya respons timbal-balik. Hal ini sesuai dengan tipe dasar pendidikan yang dikemukakan oleh Randall Collins, seperti yang dikutip oleh Sanderson, yakni: 1) pendidikan keterampilan dan praktis, yakni pendidikan yang dilaksanakan untuk memberikan bekal keterampilan maupun kemampuan teknis tertentu agar dapat diaplikasikan kepada bentuk mata pencaharian masyarakat; 2) pendidikan kelompok status, yakni proses pembelajaran dan pengajaran yang diupayakan untuk sebuah prestise, simbol serta hak-hak istimewa kelompok elit atau kelompok tertentu dalam masyarakat atau lapisan sosial; 3) pendidikan birokratis yang diciptakan oleh pemerintah untuk melayani kepentingan kualifikasi pekerjaan yang berhubungan dengan pemerintah serta berguna sebagai sarana sosialisasi politik birokratis terhadap masyarakat. ${ }^{27}$

Ketiga tipe tersebut menggambarkan kualifikasi pemerolehan (akuisisi) pengetahuan masyarakat yang cenderung mengintrodusir penerimaan pengetahuan dalam perspektif pribadi. Kecenderungan lainnya adalah melayani

25 M. Dhavamony, Phenomenology of Religion (Gregorian: University Press, 1978), 23. Bandingkan dengan Hamzah B. Uno, Profesi Kependidikan (Jakarta: Bumi Aksara, 2007), 32-33.

${ }^{26}$ Hamzah B. Uno, Profesi Kependidikan, 33.

27 Stephen K. Sanderson, Sosiologi Makro (Jakarta: Rajawali Press, 1993), 22-23. 
kebutuhan relasinya dengan pemerintahan (birokrasi), serta kencenderungan ideal yang mempertautkan teori dengan praktik (keahlian dan keterampilan). Ketiga hal ini selalu mengalami perubahan pemaknaan, pemahaman sekaligus perubahan penerapan, meski pada tataran substansial masih berada pada tipikal yang sama. Interaksi pengetahuan individual dengan sosial dan lingkungan luar merupakan wujud konstruk relasi dalam sistem pembelajaran dan pengajaran yang mengandaikan kerja sama. Pengaruh internal dan eksternal adalah suatu hal yang alamiah yang memberi keuntungan positif bagi pengembangan pendidikan.

Dalam konteks pendidikan di Indonesia, pemikiran ini memiliki pengakuan terkait dengan penyelenggaraan pendidikan nasional yang dilaksanakan secara terus-menerus dan berkelanjutan, paling tidak dipengaruhi oleh faktor eksternal dan internal. Pengaruh eksternal adalah perkembangan dunia global, sedangkan perkembangan internal adalah perngaruh kebudayaan dan kehidupan masyarakat bangsa Indonesia. Secara khusus, Ki Hajar Dewantara menyebut hal ini dalam rangkaian strategi "Trikon". ${ }^{28}$

Strategi "Trikon" meliputi: 1) konvergen, yakni adopsi nilai dan budaya positif pendidikan di Barat untuk mengembangkan dan menyetarakan pendidikan bangsa dengan negara-negara maju; 2) konsentris, yakni merujuk pada kebudayaan bangsa dan nilai-nilai luhur untuk mengembangkan pendidikan.; 3) kontinuitas, yakni pendidikan yang dilakukan secara terus-menerus. ${ }^{29}$ Pola pendidikan dalam hal ini adalah proses mentransmisi pengetahuan tanpa melupakan nilai-nilai dan tradisi Indonesia, menyerap keunggulan nilai dan budaya luar yang positif sebagai pedoman dalam meningkatkan daya saing. Proses tersebut dilakukan secara terus-menerus seiring dengan perkembangan dan perubahan nilai, tradisi dan budaya dan kemungkinan penerimaan dan penolakan terhadapnya.

Strategi Trikon diilustrasikan dalam gambar di bawah ini:
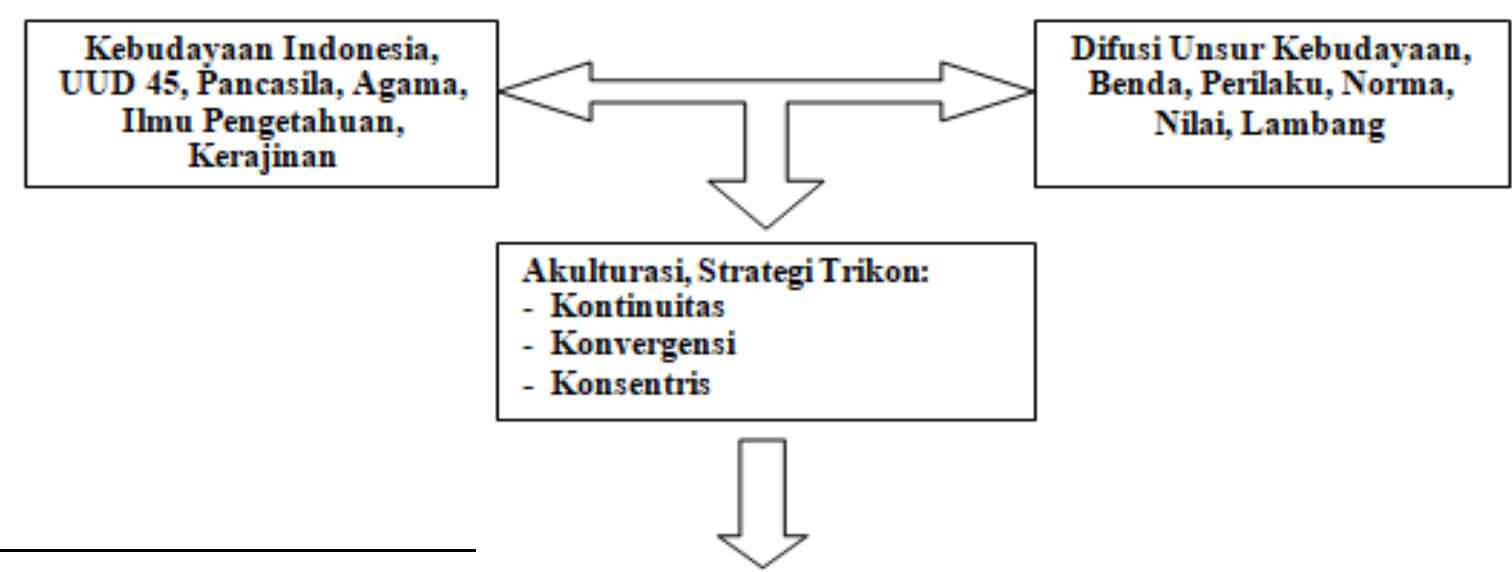

\footnotetext{
${ }^{28}$ M. Dimiyati, Landfasan Kependidikan (Jakarta: Dirjen DIKTI, P2LPTK, 1989), 198.

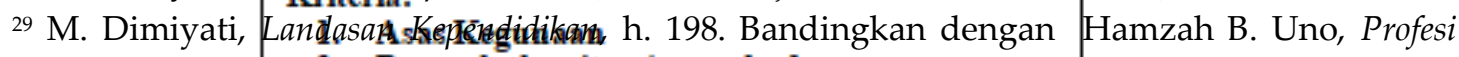
Kependidikan, hal. 34.

2. Penumbuhanitem/unsur budaya

3. Penguat/pengembangunsur budaya

4. Pengembangan bakat budaya individu

5. Survivalitas kegiatan budaya

6. Kendala unsurbudaya

7. Serap temu, kembangkanide-konsep

8. Originalitas, taat asas adaptasi

9. Konservasi, Museum, dokumentasi
} 
Strategi Trikon dalam konteks peningkatan pengetahuan dan kecerdasan bangsa. ${ }^{30}$

Gagasan tersebut menjadi tujuan pendidikan dari Taman Siswa yakni pengembangan manusia seutuhnya yang menuntut pengembangan daya yang seimbang dan selaras, sehingga yang dimaksudkan dengan manusia merdeka adalah orang yang mampu berkembang secara utuh dan selaras dengan aspek kemanusiaanya dengan menghargai dan menghormati orang lain. Dengan demikian, implementasi gagasan pemikiran Ki Hajar Dewantara tersebut ke dalam proses pendidikan menuntut suasana yang berprinsip kekeluargaan, kebaikan, empati, cinta dan penghargaan. Prinsip tersebut merupakan bagian dari budaya masyarakat yakni melihat manusia dari segi kehidupan psikologis yakni manusia yang memiliki cipta, rasa dan karsa.

Dengan demikian, pendidikan sebagai salah satu bentuk perwujudan kebudayaan manusia yang dinamis dan syarat perkembangan. Karena itu, perubahan dan perkembangan pendidikan memang hal yang seharusnya terjadi sejalan dengan perubahan budaya kehidupan. Perbaikan pendidikan pada semua tingkat terus dilakukan sebagai antisipasi kepentingan masa depan. Perubahan sosial yang merupakan kewajaran adalah prinsip umum dalam teori perubahan sosial. ${ }^{31}$ Perubahan tersebut terjadi dalam rangka mempertahankan keseimbangan dalam kehidupan masyarakat yang diliputi oleh beragam unsur, seperti unsur geografis, biologis, ekonomis atau kebudayaan. ${ }^{32}$

Proses-proses perubahan sosial tersebut diketahui dengan beberapa ciri:

1. Tidak ada masyarakat yang berhenti berkembang, karena setiap masyarakat mengalami perubahan secara lambat maupun cepat.

2. Perubahan yang terjadi pada lembaga masyarakat tertentu, akan diikuti dengan perubahan pada lembaga-lembaga sosial lainnya. Karena lembagalembaga sosial tersebut bersifat interdependen, maka sulit untuk mengisolasi

\footnotetext{
${ }^{30}$ Hamzah B. Uno, Profesi Kependidikan, 35.

${ }^{31}$ Soerjono Soekanto, Sosiologi (Jakarta: Rajawali Press, 1999), 338.

32 Soerjono Soekanto, Sosiologi, 338.
} 
perubahan pada lembaga-lembaga tertentu saja. Proses awal dan prosesproses selanjutnya merupakan mata rantai.

3. Perubahan-perubahan sosial yang berlangsung cepat biasanya mengakibatkan disorganisasi yang bersifat sementara karena berada dalam penyesuaian diri. Diorganisasi akan diikuti oleh suatu reorganisasi yang mencakup pemantapan kaidah-kaidah dan nilai-nilai baru.

4. Perubahan-perubahan tidak dapat dibatasi pada bidang kebendaan atau bidang spiritual saja, karena kedua bidang tersebut memiliki keterkaitan timbal-balik. ${ }^{33}$

Atas dasar keniscayaan perubahan, dunia pendidikan dituntut melakukan penyesuaian. Kegagapan dalam penyesuaian mengakibatkan kemunduran respons atas situasi yang berubah. Kemunduran juga akan berakibat pada munculnya dampak-dampak yang tidak diharapkan dari produk-produk dunia pendidikan, yang pada akhirnya menempatkan proses pendidikan yang tidak mampu memenuhi tujuan idealnya.

Kegagapan respons terhadap perubahan akan memunculkan proses reaktif dalam memandang berbagai dampak negatif yang ditimbulkan dari perubahan sosial. Pada gilirannya, berbagai kasus yang menimpa siswa didik, guru maupun orang tua siswa diatasi dengan tindakan-tindakan pragmatis yang bersifat sementara dan tidak memiliki efek jangka panjang. Konstalasi ini hanya menghadirkan lingkaran persoalan yang tidak kunjung berakhir. Pada saat tertentu akan lebih mudah mencari "kambing hitam" dengan menyalahkan pihak-pihak tertentu.

Menurut Winarno, kebanyakan orang mengira jalan keluar yang cepat dan tepat dari lingkaran persoalan ini hanya dengan merumuskan kurikulum yang baru, menerapkan mengajar dan mengevaluasi yang lain, mengubah pola pengelolaan, menambah besaran anggaran pendidikan, mengganti pejabat yang kurang handal, menghasilkan berbagai peraturan baru atau menunjuk menteri baru di bidang pendidikan. Semua contoh yang dilakukan tersebut tidaklah menyelesaikan persoalan. ${ }^{34}$

\section{Paradigma Baru: Solusi Pendidikan Berkelanjutan}

Dalam konteks lingkaran persoalan tersebut, yang dibutuhkan adalah kejelasan dasar dan hakikat pendidikan pada umumnya dan pendidikan nasional pada khususnya. Bukan dasar hakikat pendidikan sebagai yang dengan mudah dikemukakan oleh pendidikan "instan" atau birokrat dengan beragam "teori" seadanya berdasarkan common sense. Hakikat dan dasar pemaknaan tentang

\footnotetext{
33 Soerjono Soekanto, Sosiologi, 338-339.

34 Winarno Surakhmad, Pendidikan Nasional, 95.
} 
pendidikan yang dimaksud adalah pendidikan seperti yang bersumber dari amanah UUD 1945 yang secara jelas dan tegas menggariskan hakikat dan tujuan pendidikan. ${ }^{35}$ Berbagai perubahan instan, seperti yang disinggung di atas, hanyalah konsekuensi dari respons atas perubahan sosial yang terjadi.

Atas dasar itulah, konsep "Education for Sustainable Development"/ESD, patut untuk diajukan sebagai bahan pertimbangan dalam memandang lingkaran persoalan yang disebutkan di atas. ESD atau biasa disebut pendidikan untuk pembangunan yang berkelanjutan adalah sebentuk proses pendidikan yang lebih memiliki visi dan misi jangka panjang, tidak terikat dengan sekat-sekat respons jangka pendek dari hasil produk pendidikan yang belum sepenuhnya terakomodasi dalam upaya mewujudkan tujuan nasional dari pendidikan itu sendiri. Konsep ini tidak sebatas memandang pusat persoalan pada anak didik, namun seluruh pihak yang berkepentingan dengan pendidikan, termasuk guru, orang tua siswa maupun lingkungan di sekitar mereka.

Menurut Alex Ryan, ESD merupakan inisiatif dunia pendidikan internasional yang memandang proses pendidikan tidak hanya sebatas pendidikan dalam ruang tertentu (klasikal), tapi meliputi berbagai level perolehan pengetahuan dan sistem yang memungkin perolehan tersebut bisa dilakukan. ${ }^{36}$ Konsep tentang "berkelanjutan" berfokus pada pencapaian hasil produk pendidikan yang memiliki kualitas kemanusiaan yang lebih baik. Semua kualitas tersebut diperoleh dari persentuhan proses pendidikan dengan sumber daya budaya maupun alam sekitar. Persentuhan ini bisa saja bertentangan dengan kebijakan politik kekuasaan maupun kebijakan akademis yang berlaku pada lembaga-lembaga pendidikan tertentu. Karena ESD lebih mengandalkan pendidikan yang bersifat sistemik (pola pikir), partisipasi dan pengalaman, pemikiran kritis, kerja sama dan refleksi nilai. ${ }^{37}$

Terkait dengan itu, Smith menyatakan bahwa proses pendidikan dan pembelajaran merupakan implikasi dari pengalaman. ${ }^{38}$ Oleh karena itu, pendidikan dan pengajaran harus menyesuaikan dan mendasarkan dirinya pada pengalaman, sehingga akan tampak bahwa proses tersebut berjalan secara alamiah dan tak terelakkan. ${ }^{39}$ Dalam praktiknya, sekolah dan pendidikan masa kini seharusnya tidak terlalu banyak mendiskursuskan proses belajar dan mengajar semata, melainkan lebih pada proses mempraktikkan (doing). Persolan

\footnotetext{
35 Winarno Surakhmad, Pendidikan Nasional, 96.

36 Alex Ryan, Education for Sustainable Development and Holistic Curriculum Change (UK: The Higher Education Academy, 2011), 3.

37 Alex Ryan, Education for Sustainable Development and Holistic Curriculum Change, 3.

${ }^{38}$ F. Smith, "Let's Declare Education a Disaster and Get on with Our Lives", Phi Delta Kappan, 1995: 588.
}

${ }^{39}$ F. Smith, “Let's Declare Education a Disaster and Get on with Our Lives, 589. 
praktik tidak sekedar bersifat teknis, tapi juga pengejawantahan berbagai teori pengetahuan dalam perilaku keseharian.

Untuk menerapkan konsep tersebut, beberapa hal menjadi perlu diperhatikan, yakni: 1) fokus pembelajar dan pengajaran pada apa yang dicapai oleh siswa; 2) praktik pengajaran dan pembinaan yang didesain secara inklusif dan mengandalkan komunitas pembelajaran yang terpadu; 3) hubungan efektif antara sekolah dan budaya; 4) kualitas pengajaran merupakan tanggung jawab bagi proses pembelajaran siswa; 5) kesempatan pembelajaran didesain dengan efektif dan efesien; 6) berbagai tugas dan konteks pembelajaran yang beraneka macam harus mendukung lingkungan pembelajaran; 7) tujuan kurikulum yang efektif; 8) sistem pendidikan dan pengajaran yang bergantung pada respons siswa; 9) sistem pendidikan dan pengajaran mempromosikan orientasi pembelajaran; 10) Guru dan siswa saling menyatu dalam mewujudkan tujuan peningkatan mutu pembelajaran. ${ }^{40}$

Berdasarkan perhatian terhadap hal di atas, Gurney kemudian menunjukkan lima faktor yang bisa dipandang sebagai bentuk efektif dari proses peningkatan mutu pembelajaran dan pengajaran dalam kerangka ESD, yakni: 1) Pengetahuan guru, antusiasme dan tanggung jawab bagi sistem pembelajaran; 2) Aktivitas ruang kelas yang memotivasi hasrat untuk belajar; 3) Adanya penilaian yang objektif yang mampu meningkatkan gairah pembelajaran; 4) Terjadinya proses timbal-balik antara guru dengan siswa dalam proses pembelajaran; 5) Interaksi efektif antara guru dengan siswa dengan menciptakan lingkungan yang mengapresiasi dan merangsang pengalaman belajar. ${ }^{41}$

Menurut John Holt, terdapat banyak hal yang menyebabkan proses peningkatan pengetahuan melalui sistem pembalajaran tidak berjalan efektif. Dalam beberapa hal siswa merasakan dampak yang sangat jelas, di mana secara umum sekolah tidak mampu mengenal kualitas kehidupan pendidikan. Tampak adanya situasi yang membosankan dari aktivitas yang berulang dan menjemukan, disamping itu adalah kualitas guru yang tidak mencerahkan atau membuat suasana lebih dinamis dengan menjaga hubungan efektif dengan lingkungan sekolah. ${ }^{42}$

Berdasarkan perspektif tersebut, ESD menampilkan sebuah sistem pendidikan yang tidak hanya terfokus pada proses klasikal atau sistem pendidikan konvensional atau pedagogik tradisional yang menitikberatkan proses transmisi pengatahuan pada diri individu, baik siswa maupun guru dalam sebuah hubungan timbal-balik, tanpa memperhatikan pijakan kedua pihak

40 Philip Gurney, "Five Factors for Effective Teaching", New Zealand Journal of Teachers' Work, Vol. 4, No. 2, 2007: 89-98.

41 Philip Gurney, "Five Factors for Effective Teaching".

${ }^{42}$ John Holt, How Children Fail, (New York: Dell, 1964), 168-179. 
terbut. ${ }^{43}$ Sistem pendidikan yang juga tidak sekedar merespons dampak negatif maupun kegagalan dengan cara-cara instan, seperti yang digambarkan oleh Winarno, dengan sekedar mengganti kurikulum, mengevaluasi pola-pola belajarmengajar atau mengganti menteri di bidang pendidikan.

Perspektif ini secara umum menjelaskan bahwa prinsip pendidikan nasional adalah masalah nasional dengan berbagai aspek yang melingkupinya. Bukan hanya masalah pejabat pemerintah, tetapi masyarakat pada lapisan terbawah pun turut terlibat dan memiliki hak konstituional untuk menentukan arah kebijakan pendidikan. Semua pihak memiliki tanggung jawab dan peran serta menjadi sumber kekuatan dalam upaya melawan dehumanisasi yang menjadi dampak dari pendidikan yang tidak utuh. ${ }^{44}$

Atas dasar itu pula ESD identik dengan sistem pendidikan untuk pembangunan yang bersifat berkelanjutan. Pembangunan berkelanjutan (sustainable development) adalah sebuah perubahan, perkembangan atau pembangunan meliputi kehidupan sosial, budaya, ekonomi dan lingkungan secara simultan, berkesinambungan sehingga menghasilkan kondisi tentram, aman, nyaman baik dimasa sekarang maupun yang akan datang. ${ }^{45}$

Konsep pendidikan untuk pembangunan berkelanjutan bukan wacana baru dalam sistem pendidikan nasional. Konsep ini telah diperkenalkan pada awal tahun 2000 melalui UNESCO (United Nations Educational, Scientific and Cultural Organization) atau Organisasi Pendidikan, Ilmu Pengetahuan, dan Kebudayaan PBB merupakan badan khusus PBB yang didirikan pada 1945. Pada tahun 2002, UNESCO mendeklariskan Dekade ESD selama rentang tahun 2005 2014. Kala itu, Pada 1 Maret 2005, Direktur Jenderal UNESCO Koichiro Matsuura meluncurkan Dasawarsa ESD PBB (DESD) di New York. Dalam peluncuran itu, Matsuura menyatakan:

"Tujuan akhir Dasawarsa ini ialah bahwa pendidikan pembangunan berkelanjutan haruslah menjadi lebih daripada sekedar sebuah semboyan. Ia harus merupakan kenyataan konkret bagi kita semua - perorangan, organisasi, pemerintahan- dalam segala keputusan dan tindakan harian kita, sehingga terpenuhilah janji adanya sebuah planet yang berkelanjutan dan dunia yang lebih aman bagi anak, cucu, dan keturunan mereka. Para pelaku utama pembangunan berkelanjutan haruslah menempatkan peran mereka dalam pendidikan anak-anak, pendidikan tinggi, pendidikan nonformal dan dalam kegiatan pembelajaran berbasis masyarakat. Ini berarti pendidikan haruslah

\footnotetext{
${ }^{43}$ H.A.R. Tilaar, Perubahan Sosial dan Pendidikan, xliii.

${ }^{44}$ Winarno Surakhmad, Pendidikan Nasional, 113.

${ }^{45}$ Budi Sri Hastuti, Pendidikan untuk Pengembangan Berkelanjutan (Education for Sustainable Development) dalam Perspektif PNFI, dalam Andragogia-Jurnal PNFI /Volume 1/No 1 - Nopember 2009.
} 
berubah sehingga ia mampu menanggapi masalah-masalah sosial, ekonomi, budaya dan lingkungan hidup yang kita hadapi dalam Abad ke-21."46

Dalam konteks pendidikan Islam, pembangunan atau pengembangan berkelanjutan bukanlah hal yang baru, sebab prinsip keagamaan senantiasa menawarkan proses memiliki efek yang berkelanjutan, hingga abadi. Proses pendidikan itu sendiri digambar oleh Rasulullah Saw, sebagai proses yang dilalui sejak lahir hingga akhir hayat (log life education). Konsep tersebut bisa ditelusuri dari pemaknaan tentang pendidikan dalam beberapa definisi:

1. At-Ta'lîm. Menurut Naquib al-Attas, pendidikan bermakna sebagai pengajaran. ${ }^{47}$ Pengajaran ini bersifat pemberian atau penyampaian pengertian, pengetahuan dan keterampilan. Pengertian $a t$-ta'lîm hanya sebatas proses transfer seperangkat nilai antar manusia. Ia hanya dituntut untuk menguasai nilai yang ditransfer secara kognitif dan psikomotorik, akan tetapi tidak dituntut pada domain afektif.

2. At-Tarbiyah yang berarti mengasuh, mendidik dan memelihara. ${ }^{48}$ Istilah ini mewakili makna pendidikan Islam. Hal disebabkan karena kata tersebut memiliki arti hubungan pemeliharaan manusia terhadap makhluk Allah lainnya, sebagai perwujudan tanggung jawab di muka bumi seabagai khalifah.

3. At-Ta'dîb dapat diartikan sebagai proses mendidik yang lebih tertuju pada pembinaan dan penyempurnaan akhlak atau budi pekerti. Orientasi kata at$t a^{\prime} d \hat{\imath} b$ adalah pembentukan karakter pribadi muslim. ${ }^{49}$

Secara hakiki, konsep pendidikan Islam juga mengacu pada usaha-usaha yang dilakukan individu dan masyarakat dalam mentransmisikan nilai-nilai, kebiasaan-kebiasaan dan bentuk-bentuk ideal kehidupan mereka pada generasigenarasi untuk membantu mereka dalam meneruskan aktifitas kehidupan secara efektif dan berhasil. ${ }^{50}$

Berdasarkan pengertian tersebut, pendidikan Islam diarahkan tidak dalam tujuan jangak pendek, sekedar untuk melahirkan produk-produk kelembagaan, melahirkan menjadi manusia seutuhnya. Dengan demikian, transmisi pengetahuan tidak sekedar berupa pengetahuan teknis, namun juga nilai-nilai yang menjadi bekal hidup invidu dalam menjalani masa depan.

46 Octo Rianto, "Mengenal Lebih Dekat Dasawarsa (2005-2015) Education Sustainable Development (ESD)", dalam http://www.mediasorot.com/?p=134.

${ }^{47}$ Hasan Langgulung, Asas-asas Pendidikan Islam, Jakarta: Al-Husna Zikra, 2000, hal. 3

${ }^{48}$ Anshori LAL, Pendidikan Islam Tranformatif (Jakarta: Referensi, 2012), 8.

${ }^{49}$ Anshori LAL, Pendidikan Islam Tranformatif, 9.

${ }^{50}$ Manzoor Ahmed, Islamic Education (New Delhi: Qazi Publisher, 1990), 1. 
Konsep ESD memperkenalkan sebentuk sistem pendidikan yang bersifat holistik dan menyentuh aneka ragam kepentingan pendidikan, baik dari asalmula, proses, hingga hasil pendidikan yang hendak diwujudkan. Konsep ini menjaring unsur-unsur penting yang menopang kelangsungan masa depan. Karena itu, UNESCO menjelaskan 3 (tiga) perspektif penting masa depan yang hendak diakomodasi dalam konsep ESD, yakni perspektif sosial-budaya, perspektif lingkungan, serta perspektif ekonomi. ${ }^{51}$ Ketiga hal ini dipandang sebagai penopang penting masa depan yang justru saat ini sedang mengalami kemorosotan.

Dipandang dari sudut kepentingan yang begitu besar, konsep ESD cenderung berbicara tentang banyak hal dan bergantung pada kepentingan besar dan mendesak yang sedang dihadapi oleh pihak-pihak yang berkepentingan dengan konsep tersebut. Di negara-negara maju, konsep ESD juga digunakan dalam rangka mengakomodasi kepentingan konsumsi energi yang berkelanjutan dengan mendekatkan pendidikan pada isu-isu pelestarian alam dan lingkungan.

Dalam sistem pendidikan Islam, istilah dan pemaknaan tentang berkelanjutan (sustainablity) meliputi tujuan dri pendidikan itu sendiri. Berbagai identifikasi tentang makna pendidikan senantiasa berorientasi pada masa depan, bahkan lebih bersifat imanen dengan tujuan ukhrawi. Hal itu tergambar dalam visi umum pendidikan Islam yang melekat pada misi kenabian Nabi Muhammad Saw. Sebagai pembawa ajaran Islam. ${ }^{52}$

Misi utama kenabian Muhammad Saw. yakni membangun sebuah kehidupan manusia yang patuh dan tunduk kepada Allah SWT (Q.S. 7:66, 73; 29: 16) serta membawa rahmat bagi seluruh alam (Q.S. 21: 107; 27: 77). Kepatuhan tersebut bersifat multidimensioanl yang meliputi aspek kehidupan, termasuk ekonomi, sosial, politik, budaya, ilmu pengetahuan. ${ }^{53}$ Selain misi utama kenabian Muhammad Saw., konsep pendidikan dalam Islam juga tidak lepas hakikat keberadaan manusia di muka sebagai "khalifah" (Q.S. Fathir ayat 39 dan Q.S AlAn'am ayat 165). Hakikat sebagai "hamba" dan "khalifah" menunjukkan bahwa hubungan manusia dengan Allah serta sesama manusia diliputi oleh tanggung jawab. Tanggung jawab yang tidak sekedar kewajiban, namun juga keniscayaan agar tatanan kehidupan dunia berlangsung dengan baik. ${ }^{54}$

Dengan demikian, paradigma pendidikan Islam cenderung lebih bersifat universal yang menyertai asal-usul kehidupan manusia, tugas penghambaan serta "pengganti" Allah di muka bumi. Atas dasar itu pula, konsep pendidikan yang berkelanjutan, sebagaimana yang dicanangkan oleh UNESCO pada tahun

\footnotetext{
${ }^{51}$ http://www.UNESCObkk.org/index.php.id=3808

${ }^{52}$ Abuddin Nata, Filsafat Pendidikan Islam, Jakarta: Gaya Media Pratama, 2005, hal. 30.

${ }^{53}$ Abuddin Nata, Filsafat Pendidikan Islam, hal. 30

${ }^{54}$ Muhaimin, Paradigma Pendidikan Islam, Bandung: Rosdakarya, 2012, hal 21-23.
} 
2002, adalah sebentuk kesadaran yang pada gililrannya sudah termaktub dalam visi dan misi pendidikan Islam. Meski demikian, konsep tentang pendidikan untuk pengembangan dan pembangunan yang berkelanjutan cenderung bersifat universal dan dilandasi atas relasi individu sebagai "hamba" dan "khalifah". Asal-usul penciptaan manusialah yang melahirkan tujuan pendidikan yang bersifat universal. Sementara aspek "berkelanjutan" lebih didasari atas pemahaman universalitas tersebut yang secara tidak langsung merangkum berbagai kepentingan, tidak hanya jangka pendek, tapi juga jangka panjang.

Hal ini juga melandasi pemikiran bahwa aspek "berkelanjutan" lebih berupa pemaknaan (konsekuensi logis), ketimbang sebuah bangunan sistem pendidikan yang komprehensif, karena didasari atas kepentingan sejarah umat manusia itu sendiri yang dipenuhi dengan kegagalan untuk merealisasikan sistem pendidikan yang lebih bermanfaat bagi masa depan. Secara umum, disertasi ini hendak meneliti dan mengurai sejauhmana kontruksi Quranik tentang pendidikan untuk pembangunan "berkelanjutan", sehingga kecenderungan pendidikan Islam tidak sekedar mengetengahkan argumentasiargumentasi universal, tapi juga argumentasi-argumentasi teknis tentang sistem pendidikan "berkelanjutan" tersebut. Argumentasi-argumentasi yang dimaksud bisa diurai dari sekian banyak penafsiran tentang argumentasi universal Qur'anik dalam pembahasan disertasi ini.

Merujuk pada penjelasan latar belakang di atas, terdapat kecenderungan bersama dimana perubahan sosial (social change) merupakan sebuah keniscayaan. Berbagai dimensi kehidupan umat manusia senantiasa mengalami pertautan dengan perubahan tersebut hingga memunculkan anek ragam paradigma, tidak terkecuali dengan dunia pendidikan. Paradigma persebut diajukan untuk merespons persoalan-persoalan aktual yang terjadi dalam kehidupan sosial dan kemasyarakatan. Atas dasar itu, konsep Education for Sustainable Development (ESD) dipandang sebagai sebuah paradigma baru dalam sistem pendidikan. Kebaruan tersebut tidaklah dipandang semata sebagai kebaruan konsep, namun lebih pola penerapan serta deklarasi penggunaan yang pernah dilakukan lembaga PBB, UNESCO.

UNESCO telah mendeklarasikan 1 dasawarsa penerapan ESD dalam lingkungan global. Deklarasi ini sejalan dengan konsep pendidikan untuk Semua (Education for All, EFA) dan Sasaran Pembangunan Milenium (Millennium Development Goals, MDG). Meski pemikiran utama program ini lebih pada akomodasi terhadap persoalan lingkungan alam global yanmg semakin tergerus, namun bisa meluas kepada aspek-aspek lainnya. Tentu saja, perluasan tersebut menjadi urgensi tersendiri, mengingat pendekatan ESD yang tidak sekedar pada persoalan lingkungan, bisa menjadi alternatif solusi persoalan dalam dunia pendidikan dewasa ini. Anomali dunia pendidikan yang selalu muncul di 
hadapan publik membutuhkan solusi signifikan dan komprehensif yang menyentuh segala aspek kepentingan dalam pendidikan itu sendiri. Konsep ESD yang telah dikaji dalam berbagai jurnal dan diterapkan di berbagai negaranegara maju dan berkembang telah memasuki ruang klasikal dan kurikulum pendidikan. Hal ini menunjukkan bahwa paradigma ini memasuki berbagai level aktifitas pendidikan dan pengajaran, tidak hanya ekstrakurikuler, namun juga intrakurikuler. Diharapkan, konsep umum ini kemudian mampu melahirkan manual-manual teknis sebagai bentuk implementasi dari penerapan konsep ESD dalam sistem pendidikan nasional. Selain itu, konsep ESD yang memiliki landasan qur'anik akan memiliki legitimasi tersendiri bagi sistem pendidikan Islam. Hal ini juga akan semakin meneguhkan prinsip universalitas wawasan Qur'anik yang senantiasa relevan untuk dikaji secara terus-menerus.

ESD berwawasan Quranik menunjukkan merujuk pada eksistensi Allah SWT yang menyebut dirinya sebagai Rabb yang berarti "Pendidik". Kisah Nabi Adam as. adalah sebuah bukti hubungan langsung manusia Allah swt. secara eksistensial dan Allah swt menyebut diri-Nya dengan Rabb dengan kalimat: $W a$ idz qâla Rabbuk lil malâ'ikah innî jâ'ilun fi al-ardh khalîfah. Allah swt. benar-benar menempatkan diri-Nya sebagai pendidik ketika mendiskusikan rencana penciptaan Adam kepada para malaikat dimana sesungguhnya Dia bisa saja melakukan itu tanpa harus berbicara dengan siapa-siapa. Lalu tanpa sungkan para malaikat menyampaikan pendapatnya lalu Allah swt. kembali menegaskan penguasaan meteri yang diajarkan-Nya dengan berfirman: Innî a'lam mâ lâ ta'lamûn.

Konteks kisah ini sangat jelas berbicara tentang posisi Allah swt sebagai pendidik dengan bukti kisah ini dimulai dengan gelar Allah swt sebagai Rabb. Lalu di dalam kisah ini diceritakan bagaimana implementasi pendidikan yang dilakukan Allah swt yang senafas dengan ESD dimana dalam keadaan apapun, Allah swt selalu menjadi pendidik bagi Adam, bahkan ketika Adam dengan jelas melakukan perlawanan kepada Allah swt. dengan cara melanggar satu-satunya larangan dari Allah SWT.

\section{Kesimpulan}

Konsep pendidikan untuk pembangunan berkelanjutan merupakan salah satu perspektif dalam paradigma pendidikan. Dalam konsep tersebut, pendidikan yang diterjemahkan dalam prosesd belajar dan mengajar tidak sekedar dipandang secara klasikal dan memiliki rentang waktu tertentu. Tempatnya pun tidak sekedar mengambil wilayah belajar dan mengajar di sekolah. ESD menempatkan pendidikan sebagai proses yang panjang menuju masa depan, memiliki jangka waktu yang tidak ditentukan serta menkhususkan pada tempat tertentu. Pendidikan merupakan proses yang digeluti setiap hari dan menyentuh segala aspek kehidupan. 
Proses belajar dan mengajar berlangsung setiap saat dengan posisi yang silih berganti, baik sebagai guru maupun sebagai murid. Relasi individu dalam proses belajar dan mengajar bersifat resiprokal, dimana setiap pihak bisa menerima posisi masing-masing tanpa ada kecenderungan dominasi satu sama lain. Konsep ESD menitikberatkan pada hasil dari proses belajar mengajar sesuai dengan tujuan pendidikan. Tujuan pendidikan nasional tidak hanya berorientasi pada pembangunan fisik, tapi juga lebih dari pada itu, berkontribusi bagi pembangunan psikis. Hal itulah yang tergambar dalam tujuan pendidikan nasional yang selain mencerdaskan kehidupan bangsa, juga dan mengembangkan manusia Indonesia seutuhnya, manusia yang beriman dan bertaqwa terhadap Tuhan Yang Maha Esa dan berbudi pekerti luhur, memiliki pengetahuan dan keterampilan, kesehatan jasmani dan rohani, kepribadian yang mantap dan mandiri serta rasa tanggung jawab kemasyarakatan dan kebangsaan. Dengan kata lain, manusia seutuhnya dipandang sebagai figur manusia yang memiliki keseimbangan fisik dan psikis.

Perspektif yang sama dijelaskan dalam tujuan pendidikan Islam yang dilandasi atas pedoman Quranik. Al-Qur'an menempatkan aspek Ilahiah (ketuhanan) sebagai tujuan penting dalam proses belajar dan mengajar. Allah SWT merupakan tujuan dari segala proses dalam kehidupan, ternasuk proses belajar dan mengajar. Implikasi dari tujuan ketuhanan adalah terwujudnya manusia yang menjalankan fungsi dan tugasnya sebagai khalifah di muka bumi. Sebagai khalifah, manusia berperilaku sebagaimana Allah SWT memperlakukan hamba-Nya. Paradigma pendidikan dalam Islam menjadikan aspek ketuhanan sebagai nilai utama, dimana segala proses yang berlangsung dalam pendidikan adalah proses pengabdian.

Dalam konteks pendidikan modern, aspek ketuhanan merupakan bagian yang tidak diutamakan melebihi pencapaian tujuan-tujuan pendidikan yang menciptakan manusia profesional di bidangnya masing-masing. Pendidikan klasikal dengan rentang waktu tertentu memiliki tujuan tertentu dan memperoleh pengesahan secara akademis. Paradigma seperti ini menuai kritik dalam konsep ESD sebagai bentuk pendidikan yang tidak sensitif pada dinamika kehidupan umat manusia.

Kerusakan alam, kekerasan, kesenjangan sosial dan degradasi moral tidak bisa diselesaikan dengan paradigma pendidikan modern yang bersifat klasik. Konsep ESD melakukan kritik kepada pendidikan modern yang begitu sederhana dan sempit dalam memandang pendidikan. Pendidikan harus dipandang sebagai kebutuhan demi masa depan yang berkelanjutan dan menyentuh segala aspek kehidupan manusia. profesionalitas dan keahlian hanyalah sebagai instrumen yang justru dapat menjadi masukan bagi berbagai 
kekurangan dan kegagalan yang dialami oleh pendidikan modern dalam mewujudkan tujuan idealnya.

Meski demikian, ESD memerlukan sentuhan Qurt'anik agar tujuan pendidikan lebih terarah sesuai dengan tujuan al-Qur'an. Bagi al-Qur'an, pendidikan tidak hanya mementingkan keberlangsungan (sustainablity) masa depan, tapi juga keberlangsung hidup dan mati. Al-Qur'an meyakini kehidupan manusia tidak hanya berlangsung di dunia, tapi juga di akhirat. Lebih dari itu, pendidikan telah berlangsung sejak dalam buaian, saat manusia masih berada dalam kandungan. Pendidikan yang berlandaskan al-Qur'an memandang proses belajar da mengajar tidak sekedar dalam perspektif fisik tapi juga psikis.

Konsep ESD dapat menjadi pintu masuk bagi paradigma pendidikan Qur'anik yang bisa diterima oleh seluruh masyarakat yang heterogen. Perbedaan pandangan tentang ketuhanan dan kehidupan setelah mati tidak memiliki perbedaan signifikan, sejauh tujuan pendidikan yang bersifat jangka panjang dan tidak hanya mementingkan diri dan generasinya. Perbedaan keyakinan tentang konsep ketuhanan dan kehidupan setelah mati tidak bisa dipaksakan sebagai paradigma bersama, namun tujuan keberlangsung dapat dijadikan visi tentang pendidikan yang bersifat jangka panjang.

Konsep ESD dan al-Qur'an tentang paradigma pendidikan memiliki karakteristik yang tidak sejalan dengan paradigma modern secara umum. Modernitas yang lebih mengangungkan rasio, mengedepankan proses dan bermuara semata-mata pada profesionalisme sebagai hasil dari proses belajar dan mengajar. Meski ESD tidak memasukkan unsur ketuhanan, pandangan tentang paradigma pendidikan yang holistik memiliki landasan dalam alQur'an, dimana manusia merupakan makhluk yang multidimensi. Penggalian beragam potensi tersebut telah menunjukkan bahwa ESD tidak memandang pendidikan secara linera memiliki banyak sumber, kandungan dan metode untuk mencapai tujuan. Konsep ESD mampu melengkapi kehampaan paradigma pendidikan modern dan bisa diperkaya dengan pendekatan Qur'anik sebagai sumber pedoman dalam memandang dan menerapkan paradigma pendidikan Islam secara umum. 


\section{DAFTAR PUSTAKA}

Azra, Azyumardi, Paradigma Baru Pendidikan Nasional, Jakarta: Penerbit Kompas, 2002.

Ahmed, Manzoor, Islamic Education, New Delhi: Qazi Publisher, 1990Beijard, Douwe, et. al., (editor), Teacher Professional Development in Changing Conditions, Netherland: Springer, 2005

Anshori LAL, Pendidikan Islam Tranformatif, Jakarta: Referensi, 2012.

Assegaf, Abd. Rachman, Politik Pendidikan Nasional, Yogyakarta: Kurnia Alam, 2005.

Desta, Asayehgn, Environmentally Sustainable Economic Development, Westport, CT: Praeger, 1999.

Dhavamony, M., Phenomenology of Religion, Gregorian: University Press, 1978

Dimiyati, M., Landasan Kependidikan, Jakarta: Dirjen DIKTI, P2LPTK, 1989

Al-Farmawi, Abd al-Hayyi., al-Bidâyah Fî al-Tafsîr al-Maudhû'i, Kairo: al-Hadhârât alGharbiyyah, 1977.

Gunawan, Heri, Pendidikan Islam, Bandung: Rosdakarya, 2014.

Gurney, Philip, "Five Factors for Effective Teaching”, dalam New Zealand Journal of Teachers' Work, Volume 4, issue 2, 89-98, 2007.

Hale, Monica dan Mike Lachowicz, The Environment, Employment, and Sustainable Development, London: Routledge, 1998

Holt, John, How Children Fail, New York: Dell, 1964.

Husu, Jukka, "Analyzing Teacher Knowledge in its Interactional Positioning", dalam Douwe Beijard, et. al., (editor), Teacher Professional Development in Changing Conditions, Netherland: Springer, 2005.

Idi, Abdullah, Sosiologi Pendidikan, Jakarta: Rajawali Press, 2010.

Johson, Burke, dan Larry Christensen, Educational Research Quantitative, Qualitative, and Mixed Approaches, Boston: Pearson Education, 2004.

de Jong, S.C.N., Sosiologi Pendidikan, Jakarta: PT Sangkala Pulsar, 1984.

Kartanegara, Mulyadi, Integrasi Ilmu sebuah Rekonstruksi Holsitik, Bandung: Mizan bekerjasama dengan UIN Jakarta Press, 2005.

Khozin, Kahazanah Pendidikan Agama Islam, Bandung: Rosdakarya, 2013.

Langgulung, Hasan, Asas-asas Pendidikan Islam, Jakarta: Al-Husna Zikra, 2000.

Ma'lûf, Louis, Qâmûs al-Munjî̀ Fî̀ al-Lughah wa al-A'lâm, Beirut: Mathba'ah alKatulikiyyah, 1927.

Al-Marbawi, Muhammad Idris, Qâmûs al-Marbawî̀, Mesir: Mushthafâ al-Bâbî alHalabî, 1350.

Minarti, Sri, Ilmu Pendidikan Islam, Jakarta: Amzah, 2013.

Moleong, Lexy J., Metodologi Penelitian Kualitatif, Bandung: Remaja Rosdakarya, 2007. Muhaimin, Paradigma Pendidikan Islam, Bandung: Rosdakarya, 2012. 
Muhadjir, Noeng, Metodologi Penelitian Kualitatif, Yogyakarta: Rake Sarasin, 2000.

Muhsin, Bashori dan Abdul Wahid, Pendidikan Islam Kontemporer, Bandung: Refika Aditama, 2009.

Nata, Abuddin, Filsafat Pendidikan Islam, Jakarta: Gaya Media Pratama, 2005 , Metodologi Studi Islam, Jakarta: RajaGrafindo Persada, 2003.

Nazir, Muhammad, Metode Penelitian, Jakarta:Ghalia Indonesia, 1998.

Ryan, Alex, Education for Sustainable Development and Holistic Curriculum Change, UK: The Higher Education Academy, 2011.

Sanderson, Stephen K., Sosiologi Makro, Jakarta: Rajawali Press, 1993.

Sanjaya, Wina, Pembelajaran dalam Implementasi Kurikulum Berbasis Kompetensi, Bandung: Sinar Baru Algesindo, 2001.

Sirozi, Politik Kekuasaan, Jakarta: Rajawali Press, 2010.

Smith, F., "Let's Declare Education a Disaster and Get on with Our Lives, dalam Phi Delta Kappan, 1995.

Soekanto, Soerjono, Sosiologi, Jakarta: Rajawali Press, 1999.

Subiakto, Henry, Analisis Isi, Manfaat dan Metode Penelitiannya, dalam Bagong Suyatno \& Sutisnah (Ed.), Metode Penelitian Sosial: Berbagai Alternatif Pendekatan, Jakarta: Kencana Prenada Media Group, 2005.

Sukmadinata, Nana Syaodih, Metode Penelitian Pendidikan, Bandung: Rosdakarya, 2006.

Suparno, Paul, Filsafat Konstruktivisme dalam Pendidikan, Yogyakarta: Kanisius, 1997

Surakhmad, Winarno, Pendidikan Nasional: Strategi dan Tragedi, Jakarta: Penerbit Kompas, 2009.

Suriasumantri, Jujun, Filsafat Ilmu, Jakarta: Gramedia, 1980.

Suryabrata, Sumardi, Metodologi Penelitian, Jakarta: RajaGrafindo Persada, 2006.

Thompson, An Outline of The History of Education, New York: Barnes \& Noble, 1951.

Tilaar, H.A.R., Kaleidoskop Pendidikan Nasional, Jakarta: Penerbit Kompas, 2012. Kekuasaan dan Pendidikan, Magelang: Indonesiatera, 2003.

Pendidikan Nasional: Arah Ke Mana?, Jakarta: Penerbit Kompas, 2012.

Pengembangan Kreativitas dan Enterpreneurship, Penerbit Kaompas, 2012 Perubahan Sosial dan Pendidikan, Jakarta: Grasindo, 2002.

Turner, Bryan S., Orientalism, Postmodernism, and Globalism, London: Routledge, 1994. Uno, Hamzah B., Profesi Kependidikan, Jakarta: Bumi Aksara, 2007

Echols, John M., dan Hasan Shadily, Kamus Inggris-Indonesia, Jakarta: Gramedia, 2003 Vaizey, John, Pendidikan di Dunia Modern, Jakarta: Gunung Agung, 1987

Badan Pusat Statistik, No. 78/11/Th.XVI, 6 November 2013.

Hastuti, Budi Sri, Pendidikan untuk Pengembangan Berkelanjutan (Education for Sustainable Development) dalam Perspektif PNFI, dalam Andragogia-Jurnal PNFI /Volume 1/No 1 - Nopember 2009. 
Rianto, Octo, “Mengenal Lebih Dekat Dasawarsa (2005-2015) Education Sustainable Development (ESD)", dalam http://www.mediasorot.com/?p=134.

http://sinarharapan.co/index.php/news/read/29900/2013-tawuran-pelajar-meningkattajam.html.

http://www.radioaustralia.net.au/indonesian/2012-12-20/kekerasan-di-sekolahmeningkat-mendesak-kebijakan-sekolah-ramah-anak/1063558.

http://www.UNESCObkk.org/index.php.id=3808 